\title{
Long-term mineral transformation of Ca-rich oil shale ash waste
}

Kristjan Leben ${ }^{\mathrm{a}^{*}}$, Riho Mõtlep ${ }^{\mathrm{a}}$, Peeter Paaver ${ }^{\mathrm{a}}$, Alar Konist ${ }^{\mathrm{b}}$, Tõnu Pihu ${ }^{\mathrm{b}}$, Päärn Paiste ${ }^{\mathrm{a}}$, Ivo Heinmaa $^{\mathrm{c}}$, Gunnar Nurk ${ }^{\mathrm{d}}$, Edward J. Anthony ${ }^{\mathrm{e}}$, Kalle Kirsimäe ${ }^{\mathrm{a}}$

a - Department of Geology, University of Tartu, Ravila 14A 50411 Tartu, Estonia

b - Department of Energy Technology, Tallinn University of Technology, Ehitajate tee 5, 19086 Tallinn, Estonia

c - National Institute of Chemical Physics and Biophysics, Akadeemia tee 23, 12618 Tallinn, Estonia

d - Institute of Chemistry, University of Tartu, Ravila 14A, 50411 Tartu, Estonia

e - Centre for Combustion and CCS, Cranfield University, College Road, MK43 0AL, Cranfield, UK

* Corresponding author: E-mail: kristjan.leben@ut.ee

\begin{abstract}
:
Power generation and other industries using solid fossil fuels like coal, lignite, oil shale and peat are responsible for producing large quantities of solid residues that are often chemically reactive and/or unstable and are disposed in holding ponds and deposition sites. Stability and long-term behaviour of such deposits are typically studied in short-term laboratory experiments that cannot describe nor predict long-term changes taking place in these materials. Here, we study long-term ( $>40$ years) transformations, in highly alkaline conditions, of the Ca-rich ash deposit in Estonia composed of oil shale processing residues from the Eesti power plant. Detailed mineralogical,
\end{abstract}


chemical and micromorphological analyses using X-ray diffraction, X-ray fluorescence, ${ }^{29} \mathrm{Si}$ nuclear magnetic resonance, scanning electron microscopy and other methods were applied in order to identify the composition of the waste with a focus on formation and transformation of semicrystalline phases in the deposit. The results show progressive formation of calcium-silicatehydrate (C-S-H) type phase at the expense of silicate minerals and amorphous glass phases with increasing depth and age of the sediments, from about $25 \%$ in the upper part of the depository to over $60 \%$ in the oldest-deepest part. This demonstrates that over time the high alkalinity of the ash is responsible for initiating natural alkali-activation. The formation of C-S-H-type phases increases the mechanical strength of the sediment and ensures long-term stability of waste deposits. These findings may encourage the use of these ashes in binder or other construction material production or as construction aggregates.

Keywords: C-S-H; Alkali-activation; Oil shale ash; Mineralogy; Stability; Ash utilisation 


\section{Introduction}

Utilisation of fossil fuels is a major source of environmental pollution. Firing and retorting of solid fossil fuels like coal, lignite, oil shale and peat emit vast quantities of greenhouse gases, and produce large quantities of solid residues that pose additional environmental risk. More than 750 Mt of coal combustion products are generated globally every year (Heidrich et al., 2013). These residues can be beneficially reused, for example, in the manufacture of concrete and construction materials (Gomes et al., 2016; McCarthy and Dhir, 1999; Petzrick et al., 2017). However, ash utilisation rates vary from country to country ranging between $90 \%$ and $<10 \%$ and, as a result, substantial amounts of waste are dumped in holding ponds and disposal sites. The potential environmental impact of such wastes depends on their composition, which is a combination of the geological origin of fuel, combustion/retorting processes, methods of waste disposal, and overall climatic conditions. However, in general, most such residues are chemically reactive upon hydration and their phase composition is in a metastable state due to various recrystallisation reactions (Fulekar and Dave, 2007).

Kerogenous oil shales (OS) produce highly alkaline wastes, as do similar waste remains after firing lignites and high-Ca coals (Filippidis and Georgakopoulos, 1992; Lecuyer et al., 2001; Zhao et al., 2010). OS deposits are found worldwide but these large reserves are exploited only in a few countries, mostly because of the low heating value and environmental concerns. Even the best quality OS like the Estonian kukersite OS have heating values of 8-12 MJ/kg (Ots, 2006) and generate $\sim 45-53 \%$ of solid residues upon combustion (Loo et al., 2018). This is much greater than the $5-20 \%$ solid waste left from typical coal firing.

The average utilisation rate of coal combustion products in the European Union is more than $90 \%$ (Heidrich et al., 2013). Class F ash - high silica and alumina - possesses pozzolanic properties and 
can be successfully used as filler and/or raw material for the production of different binders (Van Deventer et al., 2012). Class $\mathrm{C}$ ash, rich in Ca, despite having self-cementing properties, is much less used (Paiste et al., 2016). As an example, in Estonia over $15 \mathrm{Mt}$ of calcareous OS is mined annually and 6-8 Mt of Ca-rich ash is produced, but only a few percent is reused, with the rest landfilled in large disposal sites (Konist et al., 2016; Mõtlep et al., 2010).

There are two major concerns with such large waste disposal sites - their mechanical stability (including ash hardening/litification) and environmental impact. Mechanical stability of disposal sites is largely controlled by the site construction itself and the reactivity and mineral alteration of the disposed material. C-type ash formed after Estonian OS processing is rich in free lime $\left(\mathrm{CaO}_{\text {free }}\right)$ and anhydrite $\left(\mathrm{CaSO}_{4}\right)$ with the average $\mathrm{CaO}_{\text {free }}$ content of the bulk ash varying between $2-25 \mathrm{wt} \%$ (Bityukova et al., 2010). Hydration of ash transported to disposal sites in water slurry results in a variety of secondary Ca-minerals - calcium hydroxide (portlandite), ettringite, hydrocalumite, etc., providing sufficient self-cementation of the material for building high (up to $45 \mathrm{~m}$ ), self-sustaining steep-walled waste depositories. However, the long-term behaviour and stability of these waste deposits are determined by diagenetic processes inside the deposit. These processes can affect its structural integrity, leading to deposit failure and/or potential leaching of hazardous components and contamination of the surroundings. Moreover, the waters draining off the deposits reach equilibrium with secondary Ca-phases and are highly alkaline $(\mathrm{pH}>12)$, posing environmental risks (Blinova et al., 2012) that need to be controlled in the short and long term (Astrup et al., 2006).

Secondary Ca-phases forming upon hydration of OS ash are metastable in the open environment and decompose/recrystallise over time. Liira et al. (2009), Mõtlep et al. (2010) and Velts et al. (2013) have assessed the transformation and long-term alkalinity potential of OS ash sediments 
and have suggested, based on modelling and mineralogical data, that the diagenetic transformation of hydrated ash sediments in open conditions is governed by carbonation reactions. Whereas, due to the slow transport of $\mathrm{CO}_{2}$, the full neutralisation of a $45-\mathrm{m}$-thick ash sediment deposit by percolating precipitation water would require hundreds of thousands of years (Mõtlep et al., 2010).

Transformation of hydrated Ca-rich OS ash and its initial self-cementation are well characterised in laboratory-scale experiments (Liira et al., 2009; Raado et al., 2014; Uibu et al., 2016) but ash material transformations and long-term stability under real environmental conditions have been poorly studied. Similarly, the in situ studies of mechanical and mineralogical stability of waste depositories (Nguyen et al., 2015; Yvon et al., 2006) have focused on short-term changes, those occurring after only a few years. However, slow mineral and chemical transformations can occur for extended periods of time until the waste reaches equilibrium with the environment.

Here we undertake a detailed chemical, mineralogical and microstructural study of Ca-rich ash sediments accumulated in the ash depository at Eesti Power Plant (PP), Estonia. This oil-shalefiring plant was commissioned in 1969 and the drill core material penetrating the full thickness of the ash sediments recover the depositional and diagenetic history of the Ca-rich ash waste since the establishment of the depository nearly fifty years ago. We aim to elucidate the long-term diagenetic transformation of the Ca-rich ash wastes and assess long-term stability of ash deposits of this type. We have also discussed applications of waste materials conditioned and stabilised for decades under natural highly alkaline conditions in different backfilling and construction applications.

\section{Materials and Methods}


The samples were taken from a drill core from the ash disposal site at Eesti PP, north-eastern Estonia (Fig. 1). Total thickness of the deposit at the drilling site was $37.5 \mathrm{~m}$. Altogether 69 samples for mineral and 34 for chemical composition were taken across the whole sequence. The groundwater level in the drill hole was measured at a depth of $6.6 \mathrm{~m}$.

The X-ray diffraction (XRD) analysis of ash waste materials was carried out on the powdered unoriented preparations with a Bruker D8 Advance diffractometer. Rietveld analysis of XRD patterns was carried out using the Topas code; the relative error of quantification is better than $10 \%$ for major phases (content $>5 \mathrm{wt} \%$ ) and better than $20 \%$ for minor phases (content $<5 \mathrm{wt} \%$ ). For putative C-S-H gel the estimated relative error is in the same range with minor phases (i.e. up to 20\%). Calcium silicate hydrate (C-S-H, in cement notation) phase was modelled via a tobermoritelike structure that provides a rough estimate of this gel-like semicrystalline compound. Chemical composition was determined in pressed pellets by X-ray fluorescence spectroscopy (XRF) using a Rigaku Primus II spectrometer. The loss on ignition (LOI) of the samples was determined by heating at $950{ }^{\circ} \mathrm{C}$ for $2 \mathrm{~h}$. Common phases often present in cement are given in cement notation (Taylor, 1997): $\mathrm{C}=\mathrm{CaO} ; \mathrm{S}=\mathrm{SiO}_{2} ; \mathrm{H}=\mathrm{H}_{2} \mathrm{O} ; \mathrm{A}=\mathrm{Al}_{2} \mathrm{O}_{3} ; \mathrm{F}=\mathrm{Fe}_{2} \mathrm{O}_{3}$.

Imaging and chemical analyses of carbon-coated polished aggregates and Pt-coated freshly broken surfaces were carried out with a Zeiss EVO 15MA scanning electron microscope (SEM) equipped with an Oxford X-MAX energy-dispersive detector system (EDS) and AZTEC software for element analysis and distribution mapping.

Attenuated Total Reflectance Fourier Transform Infrared spectroscopy (ATR-FTIR) patterns of selected samples were measured using a micro-ATR accessory attached to a Thermo Scientific Nicolet 6700 FT-IR spectrometer. Thermogravimetric analysis (TGA) was carried out using an 
STA 449 F3 Jupiter analyser in $\mathrm{Al}_{2} \mathrm{O}_{3}$ crucibles on powdered samples first dried at $70{ }^{\circ} \mathrm{C}$. The samples were heated from 40 to $1025^{\circ} \mathrm{C}$ at a rate of $10{ }^{\circ} \mathrm{C} / \mathrm{min}$ in a $\mathrm{N}_{2}$ flow of $60 \mathrm{~mL} / \mathrm{min}$.

Nuclear magnetic resonance ${ }^{29} \mathrm{Si}$ MAS-NMR spectra were recorded on a Bruker AVANCE-II NMR spectrometer at $8.5 \mathrm{~T}$ magnet $\left({ }^{29} \mathrm{Si}\right.$ resonance frequency of $\left.71.4 \mathrm{MHz}\right)$ using single-pulse excitation and a home-built MAS probe for $10 \mathrm{~mm}$ zirconia rotors. The sample was rotated at 5 $\mathrm{kHz}$, the excitation pulse was $7 \mu \mathrm{s}$ (90 degree), relaxation delay $100 \mathrm{~s}$, and each spectrum is a sum of 800 accumulations. The chemical shifts are given in tetramethylsilane (TMS) scale. Deconvolution of the NMR spectra was performed using combination of Lorentzian and Gaussian line shapes (i.e. Voigt line shape).

Figure 1. The location of the ash disposal site in north-eastern Estonia and the position of the drill hole.

\section{Results}

\subsection{Mineral composition}

The mineral composition of hydrated and partly carbonated ash sediments is characterised by terrigenous phases dominated by the relatively heat-resistant silicate minerals (quartz and Kfeldspar and also, rarely, micas), and secondary mineral phases formed during thermal processing, via hydration reactions during deposition and subsequent carbonation: calcite, vaterite, portlandite (the latter is referred to in cement notation as $\mathrm{CH}$ ), ettringite, hydrocalumite, belite $\left(\mathrm{C}_{2} \mathrm{~S}\right)$, katoite (hydrogrossular), periclase, akermanite and thaumasite (Figs. 2, 3). In addition, trace amounts of 
brucite, calcium aluminate $(\mathrm{CA})$, ferrite $\left(\mathrm{C}_{4} \mathrm{AF}\right)$, gibbsite, gypsum, merwinite, and Fe-minerals magnetite and hematite were identified.

Figure 2. Characteristic X-ray diffraction patterns of ash sediments from depths of 1.0, 10.1, 20.3 and $30.5 \mathrm{~m}$ through the hydrated ash sediment deposit.

Portlandite, which forms after rapid slacking of free $\mathrm{CaO}$, shows variable content in the studied section of the ash deposits (Fig. 3). Higher portlandite content values up to $21.4 \%$ occur at $2-7 \mathrm{~m}$, 19-25 $\mathrm{m}$ and 30-33 m depth; at other intervals portlandite stays within a few percent. Calcite shows similar large variation from near-absence to $25.5 \%$ of crystalline phases, $6.1 \%$ on average. Some vaterite, the $\gamma-\mathrm{CaCO}_{3}$ polymorph, was also detected in small amounts (up to 1.5\%) (Fig. 3).

The $\mathrm{Ca}-(\mathrm{Al})-\mathrm{SO}_{4}$ minerals ettringite and thaumasite $\left(\mathrm{Ca}-\mathrm{Si}-\mathrm{CO}_{3}\right.$-sulphate) are abundant in the upper and middle parts of the section (maximum ettringite $23.7 \%$, and maximum thaumasite 32.2\%) but disappear abruptly and almost completely below $21 \mathrm{~m}$ (Fig. 3). Hydrocalumite, the main $\mathrm{Ca}-\mathrm{Al}$ hydrate phase and katoite content show opposing trends from the top of the deposit to the bottom: hydrocalumite (a few percent to $10.6 \%$ ) is well represented on the upper part and less at the lower part, whereas Ca-Al silicate hydrate mineral katoite (hydrogarnet) shows an opposite trend (Fig. 3).

Calcium silicate minerals (belite, akermanite and merwinite) and also calcium aluminates (including ferrite materials $\left(\mathrm{C}_{4} \mathrm{AF}\right)$ and monocalcium aluminate $(\mathrm{CA})$ ) that form in hightemperature firing of $\mathrm{OS}$ in reactions between $\mathrm{CaO}, \mathrm{MgO}, \mathrm{SiO}_{2}, \mathrm{Fe}_{2} \mathrm{O}_{3}$ and $\mathrm{Al}_{2} \mathrm{O}_{3}$, are characteristic of raw unhydrated ash. Their content in ash sediments varies between 4.1 and $22.8 \%$. 
At the same time the share of the (semiamorphous) C-S-H phase increases with depth from about $25 \%$ at the surface to over $60 \%$ in the deeper section.

Thermally-resistant terrigenous minerals (quartz-Q, K-feldspar and K-mica) were detected in varying amounts throughout the sequence. Q, K-flds and mica follow similar trends throughout the studied section, more in the upper and middle parts and less at deeper sections.

Figure 3. Mineral composition (wt\%) of studied samples in the cross-section of the deposit by mineral groups. Legend: Portlandite; Carbonates $=$ calcite and vaterite; $\mathrm{Ca}-(\mathrm{Al})-\mathrm{SO}_{4}=$ ettringite and thaumasite; $\mathrm{Ca}-\mathrm{Al}-\mathrm{OH}=$ hydrocalumite, hydrogarnet and gibbsite; $\mathrm{Ca}-\mathrm{Si} / \mathrm{AlO}=\mathrm{C}_{2} \mathrm{~S} /$ belite, akermanite, $C_{4} A F, C A$, merwinite; $C-S-H=C a-S i$-hydrate phase; and Terrigenous = quartz, $K$ feldspar and mica. The relative error of quantification is better than $10 \%$ for major phases (content $>5 w t \%$ ) and better than $20 \%$ for minor phases (content $<5 w t \%$ ). For $C-S-H$ gel the estimated relative error is in the same range with minor phases.

\subsection{Chemical composition}

The chemical composition of the ash sediments shows a similar variation to the mineral composition (Fig. 4). The main chemical components $\mathrm{CaO}$ and $\mathrm{SiO}_{2}$ have opposing trends in the cross-section. Calcium oxide content ranged from $25.5-50.9 \%$ and its mean value was $40.9 \%$. Silica content stayed between $12.5 \%$ and $27.6 \%$ with a mean value of $19.6 \%$ in the analysed ash samples. With few exceptions, the contents of $\mathrm{Al}_{2} \mathrm{O}_{3}$ and $\mathrm{MgO}$ varied within a few percent. $\mathrm{Al}_{2} \mathrm{O}_{3}$ ranged from 4.6-11.9\%. Higher values of $\mathrm{Al}_{2} \mathrm{O}_{3}$ were detected in surface layers and at depths of 11 to $17 \mathrm{~m}$. The content of $\mathrm{MgO}$ stayed between $1.2 \%$ and $3 \%$. The contents of $\mathrm{SO}_{3}$ and $\mathrm{K}_{2} \mathrm{O}$ both 
varied with an amplitude of around $5 \% . \mathrm{SO}_{3}$ content stayed between $2.6 \%$ and $9.2 \% . \mathrm{K}_{2} \mathrm{O}$ content was under $1 \%$ in several samples and varied from $0.8-5.7 \%$. $\mathrm{Fe}_{2} \mathrm{O}_{3}$ content in the analysed samples was stable, varying from $2.8-4.4 \%$.

Loss on ignition did not show significant fluctuations (Fig. 4). The total mass loss at $950{ }^{\circ} \mathrm{C}$ varied from $14.9 \%$ to $25.7 \%$ with a mean value of $17.5 \%$.

Figure 4. Variation of the chemical composition in the studied section. LOI = loss on ignition; other $=\mathrm{TiO}_{2}, \mathrm{P}_{2} \mathrm{O}_{5}, \mathrm{Cr}_{2} \mathrm{O}_{3}$ and $\mathrm{Cl}$.

\subsection{Microstructure}

A scanning electron microscopy (SEM-EDS) study was undertaken to characterise sediment micromorphology development through aging of the ash deposit, and to estimate its phase composition (Figs. 5, 6).

Sediments at shallow depths $(<10 \mathrm{~m})$ are relatively porous and composed of Si-Ca-(Al) solid spheres or (partially) hollow cenospheres, in a matrix composed of variable grain-sized calcite, portlandite and residual terrigenous minerals (Fig. 5). The size of spheres ranged from less than $10 \mu \mathrm{m}$ to greater than $100 \mu \mathrm{m}$. Small $<5 \mu \mathrm{m}$-diameter Fe-rich spheres are commonly dispersed in sediment matrix. The Si-Ca composition of spheres show limited alteration and dissolution with typically few-micron-thick leaching zones at the outer perimeter (Fig. 5c).

Alteration and recrystallisation intensity increase with the depth and by $10 \mathrm{~m}$ depth the glassy spheres are replaced by flaky-fibrous Ca-Si-hydrate masses (Fig. 5d) and other secondary phases 
such as thaumasite and ettringite acicular-shape meshes (Fig. 6). EDS analyses of Ca-Si-hydrate phase show a $\mathrm{Ca} / \mathrm{Si}$ wt $\%$ ratio of about $1.5-2$ (Fig. 5 spectra). Semicrystalline masses of C-S-H often show increased Al, suggesting possible formation of more complex forms of hydrate phases such as C-A-S-H.

Figure 5. Backscattered electron images of polished sediment at shallow depths. (a) General view of sample from a depth of $2.5 \mathrm{~m}$. (b) Si-Ca-(Al) (ceno-)sphere at $2.5 \mathrm{~m}$ depth. (c) Glassy sphere with alteration rim at $10.1 \mathrm{~m}$ depth. (d) Recrystallised sphere at $10.1 \mathrm{~m}$ depth.

Figure 6. Secondary electron images of broken surfaces. (a) Portlandite overgrown with ettringite/thaumasite lath-shaped aggregates, depth $4.3 \mathrm{~m}$. (b) Spherical recrystallised particles consisting mainly of $\mathrm{Ca}$ and $\mathrm{Si}$ exhibit in some cases fibrous micromorphology that can be associated with Type I C-S-H (Taylor, 1997). (c) C-S-H flaky or needle-like bundles associated with Type I C-S-H (Stutzman, 2001; Taylor, 1997). (d) Partially dissolved and recrystallised spherical particle, depth $33.6 \mathrm{~m}$.

\subsection{ATR-FTIR}

ATR-FTIR spectra of samples from $2.9 \mathrm{~m}$ and $22.8 \mathrm{~m}$ (Fig. 7) show a characteristic band around $3642 \mathrm{~cm}^{-1}$ that can be assigned to O-H stretching of higher portlandite content (Paiste et al., 2017), which is confirmed by XRD analysis of these samples. These samples and a sample from $34.0 \mathrm{~m}$ show in their spectra C-O stretching bands around $1450 \mathrm{~cm}^{-1}$, indicative of carbonates, while the 
band at $874 \mathrm{~cm}^{-1}$ is due to out-of-plane bending of carbonate ions (Yu et al., 1999). The band at $960 \mathrm{~cm}^{-1}$ is indicative of $\mathrm{Si}-\mathrm{O}$ stretching vibrations and can be associated with the presence of $\mathrm{Q}^{2}$ Si-sites possibly in C-S-H-type phases (Paiste et al., 2017; Yu et al., 1999). This band is also present in all spectra but shows growing intensity with sample depth, which is also supported by higher C-S-H-type phase content determined in the lower part of the section by XRD analysis. The band at $599 \mathrm{~cm}^{-1}$ can be attributed to Si-O(-Si) vibrations and a band around $445 \mathrm{~cm}^{-1}$ on all spectra to deformation of $\mathrm{SiO}_{4}$ tetrahedra (Yu et al., 1999).

Figure 7. Characteristic ATR-FTIR spectra of ash sediments from different depths.

\subsection{TGA}

Thermogravimetric analysis was carried out to help qualitatively identify portlandite and different hydrate phases including X-ray amorphous phases such as C-S-H. The multitude and overlapping phases in oil shale ashes, however, make quantitative estimation unreliable (Scrivener et al., 2016). TGA lines with higher mass loss at lower temperatures over $100{ }^{\circ} \mathrm{C}$ in samples from depths of 18.7 and $20.9 \mathrm{~m}$ (Fig. 8) can be associated with the higher composition of hydrate phases ettringite and thaumasite in these samples (Scrivener et al., 2016). Characteristic rapid mass loss at around $400-450{ }^{\circ} \mathrm{C}$ is due to dehydroxylation of $\mathrm{Ca}(\mathrm{OH})_{2}$ (Alarcon-Ruiz et al., 2005; Scrivener et al., 2016; Ukrainczyk et al., 2006). The mass losses at around $600-700{ }^{\circ} \mathrm{C}$, the most prominent in samples from depths of $2.9,18.7,20.9$ and $22.8 \mathrm{~m}$, can be assigned to $\mathrm{CO}_{2}$ loss mainly from carbonates (Frías et al., 2016; Scrivener et al., 2016). That is best observed in a sample from 18.7 $\mathrm{m}$ depth with two-stage mass loss, starting from around $500{ }^{\circ} \mathrm{C}$, with the second step starting 
around $750{ }^{\circ} \mathrm{C}$. This mass loss, however, can also be attributed to amorphous $\mathrm{CaCO}_{3}$ or thaumasite (Alarcon-Ruiz et al., 2005; Scrivener et al., 2016). Identification of C-S-H-type phases is complicated from TGA analysis, but mass loss of $\sim 18 \%$ without clear peaks seen in the sample at a depth of $34.0 \mathrm{~m}$ can be tentatively attributed to C-S-H (Scrivener et al., 2016; Zhang and Ye, 2012) and other possible X-ray amorphous phases.

Figure 8. TGA patterns of studied samples from different depths of the ash deposit.

\section{6 ${ }^{29} \mathrm{Si}$ MAS-NMR}

NMR spectra of selected ash samples were analysed to characterise primary and secondary silicate phases including semicrystalline C-S-H. The recorded spectra (Fig. 9) show detection of $\mathrm{Q}^{0} \mathrm{Si}$ sites associated with $\mathrm{C}_{2} \mathrm{~S}$ (belite) in two forms, $\beta-\mathrm{C}_{2} \mathrm{~S}$ and $\gamma-\mathrm{C}_{2} \mathrm{~S}$, marked by two peaks with chemical shifts around -71 and $-73 \mathrm{ppm}$, respectively. The temperature in oil shale combustion is not sufficiently high to form $C_{3} S$ (alite). This is further confirmed by XRD analyses that do not show any signs of $\mathrm{C}_{3} \mathrm{~S}$ phase in ash materials. Therefore, the peaks with chemical shifts often assigned to $\mathrm{C}_{3} \mathrm{~S}$ have been interpreted as $\mathrm{C}_{2} \mathrm{~S}$ phases. The peaks at around $-79,-81.9,-83.5,-85$, and -89 ppm mark the different Si-tetrahedra positions, $\mathrm{Q}^{1}, \mathrm{Q}^{2}(1 \mathrm{Al}), \mathrm{Q}_{\mathrm{b}}{ }_{\mathrm{b}}$ (bridging), $\mathrm{Q}_{\mathrm{p}}^{2}$ (pairing) and $\mathrm{Q}^{3}$, respectively, related typically to C-S-H-type phases. An amorphous glassy phase can also be interpreted as a shallow wide peak at around -91 to $-95 \mathrm{ppm}$. The peak at around $-107 \mathrm{ppm}\left(\mathrm{Q}^{4}\right)$ is attributed to quartz and the peak at $-67 \mathrm{ppm}$ on the spectrum of the sample from $20.9 \mathrm{~m}$ depth can be putatively interpreted as nesosilicate $\mathrm{CaMgSiO}_{4}$ (Chang et al., 2016; Magi et al., 1984; Myers et al., 2015; Paiste et al., 2017; Richardson, 1999). 
The NMR spectra show significant change along the depth profile. Wide peaks representing amorphous glass are clearly distinguishable and prominent in two most shallowly-buried samples (2.9 and $11.2 \mathrm{~m}$ ), but these peaks diminish with increasing depth indicating dissolution and recrystallisation of the glass phase over time. A similar trend is evident in $\mathrm{Q}^{0}$ peaks showing relative decrease in intensity to near-disappearance in the deepest/oldest sample that is consequently accompanied by a relative increase in different $\mathrm{Si}$-sites of the chained silicates $\left(\mathrm{Q}^{1}\right.$, $\mathrm{Q}^{2} \mathrm{~b} / \mathrm{Q}^{2}(1 \mathrm{Al})$ and $\left.\mathrm{Q}^{2} \mathrm{p}\right)$. A distinct peak at -89.1 ppm corresponding to a $\mathrm{Q}^{3}$ site was detected only in one sample from $22.8 \mathrm{~m}$ depth. The deepest sample studied, from $34.0 \mathrm{~m}$ depth, shows an intense peak at $-81.8 \mathrm{ppm}$ that can be assigned as representing $\mathrm{Q}^{2}(1 \mathrm{Al})$ units, indicating Al-tetrahedra substitution in the Si-chains, which is supported by increasing Al content in possible C-S-H-(Al)type phases in the lower part of the ash deposit detected by SEM-EDS analyses. The quartz peak $\left(\mathrm{Q}^{4}\right)$ at $-107 \mathrm{ppm}$ was detected in most of the studied samples, but it was nearly absent in the middle part of the succession.

Figure 9. NMR spectra of studied samples.

\section{Discussion}

The diagenesis of Ca-rich ash sediments has been studied mostly at the laboratory scale, suggesting the carbonation of metastable Ca-phases as a dominant process (Liira et al., 2009; Mõtlep et al., 2010; Velts et al., 2013). However, this work benefits from the new valuable data obtained by the drilling program through the whole thickness of the deposit and shows that the in situ long-term behaviour and mineralisation of Ca-rich ash sediment are dominated by alkali-activated 
recrystallisation of initial, either terrigenous or secondary, silicate phases. The final product of the long-term alteration is a semicrystalline C-S-H-type phase along with ettringite and thaumasite, whereas the carbonation is significantly subdued in deeper parts of the deposit.

The sequence of diagenetic processes starts with the fast hydration of lime into portlandite $(\mathrm{CH})$ and the hydration of anhydrite during the hydraulic deposition of ash (Liira et al., 2009), but in the long term a key role in ash recrystallisation is played by the hydration of secondary Ca-silicate minerals such as belite $\left(\mathrm{C}_{2} \mathrm{~S}\right)$. Based on NMR spectra, $\mathrm{C}_{2} \mathrm{~S}$ exists in two polymorphs: $\beta-\mathrm{C}_{2} \mathrm{~S}$ which forms at $500-680{ }^{\circ} \mathrm{C}$; and $\gamma-\mathrm{C}_{2} \mathrm{~S}$ which forms below $500{ }^{\circ} \mathrm{C}$ (Taylor, 1997). Belite hydration is one of the possible sources of C-S-H-type phases but this reaction can also lead to a secondary formation of portlandite in the ash sediments (Chen et al., 2004) by the following reaction (1):

$2 \mathrm{C}_{2} \mathrm{~S}+4 \mathrm{H} \rightarrow \mathrm{C}_{3} \mathrm{~S}_{2} \mathrm{H}_{3}+\mathrm{CH}$

The other probable source of C-S-H-type phases is the recrystallisation of aluminosilicates and dissolution of amorphous glassy phases in naturally alkaline conditions mimicking alkaliactivation (Duxson et al., 2007; Paiste et al., 2017; Yip et al., 2005). C-S-H content, as indicated by XRD pattern modelling with a tobermorite-like structure, shows increase with depth (from about $25 \%$ to over $60 \%$ ) with an exception in the middle part of the deposit. These same trends are supported by the NMR results, which show that the peaks assigned to glassy amorphous silicates and belite are higher in shallow layers and are diminished in favour of different Si-units of C-S-H-type phases in deeper layers. A similar trend in increasing amorphous phase content was already noticed by Mõtlep et al. (2010) but its nature was not discussed.

In laboratory conditions about $30 \%$ of $\beta-\mathrm{C}_{2} \mathrm{~S}$ reacts in 28 days and $90 \%$ in 1 year (Taylor, 1997). However, the alkali activation of aluminosilicate raw materials, the formation of C-S-H gel-like 
phases, and the development of strength can last for several years (de Vargas et al., 2014). The gradual increase of the C-S-H-like phase and the recrystallisation of the mineral matrix in the studied ash material, continuously deposited for almost 50 years, suggest a slow dissolution of primary crystalline and glassy silicate phases that is probably further inhibited by limited hydraulic conductivity between cemented ash layers.

The Ca-rich ash can be viewed in terms of alkali activation as a one-part alkali-activated material in a broad sense. As opposed to conventional two-part activation where typically concentrated aqueous solution of alkali hydroxide or silicate solution and solid raw material are mixed, in onepart mixtures, the dry mixture containing reactive phases is only mixed with water (Luukkonen et al., 2018). In carbonate-rich fossil fuels combustion ash, the hydration of lime $\left(\mathrm{CaO}_{\text {free }}\right)$ provides the alkaline medium for activation reactions that most probably progress in a typical alkali activation manner: ion exchange - hydrolysis - mineral/glass structure network breakdown, and release of $\mathrm{Si}$ and $\mathrm{Al}$ that undergo further speciation, gelation, reorganisation, and polymerisation (Duxson et al., 2007; Luukkonen et al., 2018; Matalkah et al., 2017). Similar reactions releasing $\mathrm{Si}$ and $\mathrm{Al}$ in alkaline environment resulting in gel formation are observed in geopolymer mixtures treated with $\mathrm{NaOH}$ (Rattanasak and Chindaprasirt, 2009).

Luukkonen et al. (2018) have pointed out that release rate and availability of Si and Al from solid silica sources used in one-part mixes are lower than in two-part alkali-activated materials. Similar behaviour of the Ca-rich ash in comparison with one-part alkali-activated materials is the formation of semicrystalline C-S-H and probably of C-A-S-H gel that are typically observed in high-calcium one-part alkali-activated systems along with other secondary hydration products like portlandite, brucite, katoite, hydrocalumite and ettringite-thaumasite (Kim et al., 2013). 
The SEM-EDS analyses of studied hydrated Ca-rich ash materials show that most of the material identified as C-S-H-type phase exhibits a high $\mathrm{C} / \mathrm{S}$ ratio of around 2 with somewhat lower ratio (around 1.5) in the deeper parts of the section. Taylor (1997) has proposed two different possible formulae of C-S-H by eliminating bridging tetrahedra from tobermorite and jennite: $\mathrm{Ca}_{5} \mathrm{H}_{2} \mathrm{Si}_{4} \mathrm{O}_{16} \cdot 8 \mathrm{H}_{2} \mathrm{O}(\mathrm{C} / \mathrm{S}=1.25)$ and $\mathrm{Ca}_{9} \mathrm{H}_{2} \mathrm{Si}_{4} \mathrm{O}_{16}(\mathrm{OH})_{8} \cdot 6 \mathrm{H}_{2} \mathrm{O}(\mathrm{C} / \mathrm{S}=2.2)$, respectively. By this, the upper C-S-H phase corresponds to Type II C-S-H (Chen et al., 2004; García et al., 2009) while the micromorphology of the C-S-H material in the lower part of the section suggests Type I (C/S around 1.5) (Stutzman, 2001; Taylor, 1997). This change might indicate further recrystallisation of C-S-H, for example, carbonation (García-Lodeiro et al., 2012), although Richardson et al. (Richardson, 2004; Richardson and Cabrera, 2000) have reported that the mean C/S ratio of C-S$\mathrm{H}$ in stoichiometric $\mathrm{C}_{3} \mathrm{~S}$ or ordinary Portland cement (OPC) pastes does not vary with age. Still, the majority of "non-synthetic" C-S-H-type phases that form from $\beta-\mathrm{C}_{2} \mathrm{~S}$, called C-S-H gel, are less ordered, exhibiting a ratio of 1.7-1.8 (Chen et al., 2004), and are probably the most common products forming in OS ashes. Alternatively, the variation in $\mathrm{C} / \mathrm{S}$ ratio can be caused by initial variability in ash composition ( $\mathrm{Ca}, \mathrm{Si}$ and $\mathrm{Al})$, fraction size, and environmental conditions (temperature and water availability).

The development of longer chains in C-S-H type phases formed in Ca-rich OS ash over time can be characterised by their mean chain lengths (MCLs) calculated using equation (2) provided by Richardson (1999) and equation (3) incorporating cross-linking $\mathrm{Q}^{3}$ units (in the case of sample from $22.8 \mathrm{~m}$ depth) by Myers et al. (2013).

$$
\overline{C L}=\frac{2}{\left(\frac{Q^{1}}{Q^{1}+Q^{2}(0 \mathrm{Al})+\frac{3}{2} Q^{2}(1 \mathrm{Al})}\right)}
$$


$\mathrm{MCL}_{[\mathrm{C}]}=\frac{4\left[\mathrm{Q}^{1}+\mathrm{Q}^{2}+\mathrm{Q}^{2}(1 \mathrm{Al})+\mathrm{Q}^{3}+2 \mathrm{Q}^{3}(1 \mathrm{Al})\right]}{\mathrm{Q}^{1}}$

The calculated chain lengths (Table 1) show the formation of longer silicate chains with increasing depth, indicated by the relative decrease in $\mathrm{Q}^{1}$ chain-end sites and increase in $\mathrm{Q}^{2}$ pairing and bridging units and, in the bottom layers, increase in $\mathrm{Q}^{3}$ units (in the sample from $22.8 \mathrm{~m}$ depth) and $\mathrm{Q}^{2}(1 \mathrm{Al})$ units (at $\left.34.0 \mathrm{~m}\right)$ tied to Al-substitution in silicate chains. This supports the hypothesis of slow recrystallisation of amorphous glassy phases and simple Ca-silicates in favour of longerchain-structured C-S-H-type phases.

Table 1. Calculated mean chain lengths (MCL) in studied samples

\begin{tabular}{lccccc} 
Depth, m & 2.9 & 11.2 & 20.9 & 22.8 & 34.0 \\
\hline MCL & 5.2 & 4.1 & 8.3 & 18.5 & 18.6
\end{tabular}

NMR analyses show the presence of $\mathrm{Q}^{2}(1 \mathrm{Al})$ units, suggesting Al-tetrahedra substitution of Sitetrahedra, and are further supported by SEM-EDS analyses that show higher Al composition in C-S-H-type phases, particularly in the sample from $33.6 \mathrm{~m}$ depth. This suggests formation of CA-S-H-type phases in the older layers of the deposit. Development of longer cross-linked (with $\mathrm{Q}^{3}$-units) products due to incorporation of $\mathrm{Al}$ is also supported by Myers et al. (2015) who have shown that cross-linking $\mathrm{Q}^{3}$ formation is promoted by $\mathrm{Al}$ presence.

The occurrence of portlandite in higher amounts at different levels throughout the section can be of both primary and secondary origin. First, the primary portlandite forms by fast slacking of lime that starts to react in the open air with atmospheric $\mathrm{CO}_{2}$ forming a stable $\mathrm{Ca}$-carbonate phase. Uibu and Kuusik (2014) have explained the preservation of portlandite in ash sediment by formation of a carbonated crust on the freshly deposited ash layers that inhibits $\mathrm{CO}_{2}$ diffusion and carbonation 
of deposited ash. Sediment ponds are episodically filled with ash slurry that is allowed to set and the next layers are added in the same manner creating a layered ash deposit. Slow or incomplete carbonation of portlandite can also help retain the stability of some mineral phases (e.g., ettringite) due to high $\mathrm{pH}$. However, secondary portlandite can form as a side product of C-S-H-type phase precipitation from hydration of $\mathrm{C}_{2} \mathrm{~S}$ (Chen et al., 2004). Assuming secondary formation of $\mathrm{CH}$, its higher concentrations could be an indication of higher initial $\mathrm{C}_{2} \mathrm{~S}$ content.

It is particularly interesting that ettringite and thaumasite show opposite trends with C-S-H phase. Ettringite, which is a typical secondary mineral in OS ash deposits (Mõtlep et al., 2010), forms early during the hydration when Al-bearing phases/glass react with water and $\mathrm{CaSO}_{4}$. Thaumasite, however, can form by dissolving C-S-H under low-temperature conditions (under $15^{\circ} \mathrm{C}$, optimally $5{ }^{\circ} \mathrm{C}$ ), and a high $\mathrm{pH}$ (10.5-13) and an abundance of water (Bensted, 1999; Crammond, 2003; Hartshorn et al., 1999; Sear, 2006). Late thaumasite and ettringite formation at the expense of CS-H phase, that is commonly observed in OPC concretes under sulphate attack (Bensted, 1999; Crammond, 2003; Hartshorn et al., 1999), can cause formation of weakened layers/zones that might be prone to collapse and/or mass wasting.

Thaumasite shows elevated content in the middle part of the section (depths between 13-21 m), where there is also a drop in C-S-H content (Fig. 3). Crammond (Crammond, 2003) suggests that thaumasite will continue to form if previously stated requirements are fulfilled and a source of $\mathrm{SiO}_{2}, \mathrm{CO}_{3}{ }^{2-}$ and $\mathrm{SO}_{4}{ }^{2-}$ ions is available. Because thaumasite has low solubility in these conditions, all other potential sources of ions (including C-S-H) will gradually dissolve to keep the pore solution at equilibrium. Ettringite, with a similar crystalline structure to thaumasite, also shows an increase in the same section of the deposit and generally follows the same trend with thaumasite. It has also been reported that the two phases can form solid solutions (Barnett et al., 2000; Torres 
et al., 2004), and that thaumasite can also transform from ettringite provided there is a source of $\mathrm{Si}^{4+}$ (for example C-S-H gel dissolution) and carbonate at low temperatures (Bensted, 1999). Experimental studies of ettringite-thaumasite solid solution formation suggest that ettringite acts as a nucleating agent or catalyst for thaumasite formation (Taylor, 1997).

These trends suggest that the $\mathrm{C}-\mathrm{S}-\mathrm{H}$ phase initially formed in this interval is undergoing dissolution and replacement with ettringite-thaumasite. Permeability and/or hydrogeological properties, and structural integrity (fracturing) of the ash sediments are yet to be determined, but this alteration can be related to the differences in ash layer permeability due to differences in ash sediment composition and/or grain size, or fracturing and enhanced water flow as a result of this. Further research should be directed into understanding the controlling mechanisms behind the thaumasite formation at the expense of C-S-H-type phases in order to inhibit or to take countermeasures to its formation that can cause the loss of the structural integrity of ash waste sites.

The general composition of ash deposited in the Eesti sedimentary ponds has remained the same over the whole period of power plant exploitation since 1969, except in the uppermost $\sim 5-8 \mathrm{~m}$ interval, where in addition to ash from pulverised fuel firing boilers the waste from circulating fluidised bed combustion boilers commissioned in 2004 has been co-deposited. However, the fuel used in the power plant (calcareous oil shale) has remained the same over this time. Since 1980 small amounts of oil retorting ash have also been co-deposited on the fields; however, this has not affected the ash composition significantly. There can be some grain-size separation during the filling of ash ponds with the ash-water slurry. However, the observed sizes of glassy spherules and cenospheres do not show variation throughout the section, suggesting that grain-size separation does not control, at least not significantly, the sediment properties. Given the present state of 
knowledge, fracturing of the sediment deposit and enhanced water flow can be suggested as the possible cause of this zone.

In general, alkali-activation-type processes with the aging of the Ca-rich ash sediments and formation of binding hydration product C-S-H phase will increase the mechanical strength of depositories with time, decrease permeability by reducing pore size, thereby ensuring long-term stability of waste deposits and, thus, enhance their reclamation possibility as future construction sites.

\section{Practical Aspects of the Research Findings}

In the coal industry older high-temperature pulverised fuel (PF) combustion boilers are gradually being replaced with more environmentally friendly low-temperature circulating fluidised bed combustion (CFB) boilers. However, as is the case with various CFB ashes around the world (Gazdič et al., 2017), these ashes generally display less favourable properties for producing construction materials. Lowered pozzolanic properties are due to relatively lower combustion temperatures, which lead to lower amounts of reactive phases in ash, specifically, lower $\mathrm{CaO}$ and glassy amorphous material content (e.g., Gazdič et al., 2017). Our results show that all deposited oil shale ash waste types have the potential to achieve better mechanical properties with the formation of C-S-H-type phases due to long-term alkali-activation induced by alkaline waters circulating in the deposits. No additional alkali or silicate additive substances are required if the reaction period is long enough to allow dissolution and recrystallisation of various crystalline and glassy silicate phases. This means that waste conditioned under alkaline conditions over a period of decades can be reused as an aggregate in road construction and building. Alternatively, the low 
reactivity CFB ashes can be used, given their activation in self-sustaining alkaline conditions, in applications where strength gain comparable with OPC mortars is not required as for backfilling of open cast quarries and underground mines. Apart from high alkalinity, Estonian oil shale ash is low in potential toxic heavy metals; the content of $\mathrm{Cd}, \mathrm{Cr}, \mathrm{Pb}$ and $\mathrm{Zn}$ is $5-10$ times lower than in typical municipal waste incineration fly ashes and lower than or comparable to average values for coal fly ash (Blinova et al., 2012; Zhao et al., 2018). Therefore, the reuse of solidified ash material is not limited in these applications.

\section{Conclusions}

Long-term transformation of Ca-rich ash waste sediments was investigated by analysing drill core material penetrating a 37.5-m-thick ash sediment deposit formed over nearly 50 years. Semicrystalline C-S-H- and possibly C-A-S-H-type phases gradually form over long periods of time in the naturally highly-alkaline conditions in the ash sediment deposit. The source of these phases is the slow dissolution and recrystallisation of primary crystalline and glassy silicate phases. Identified by XRD analyses, the content of these phases increases from about $25 \%$ near the surface to over $60 \%$ near the bottom layers. ${ }^{29} \mathrm{Si}$ NMR analyses show formation of more complexstructured C-A-S-H phases in the bottom layers, suggesting continuous diagenetic recrystallisation of silicate phases. Formation of C-S-H- and possibly C-A-S-H-type phases ensures the increased mechanical strength and long-term coherence of the deposits. However, the late formation of ettringite-thaumasite and partial dissolution of C-S-H phases in zones of enhanced permeability can cause deterioration of mechanical properties and failure of the deposits. Carbonation of portlandite, earlier considered as the main process governing Ca-rich ash sediment diagenetic transformation is inhibited, possibly due to limited diffusion of $\mathrm{CO}_{2}$ into several tens-of-metres- 
thick sediment piles. This, however, predicts that the infiltrating waters draining off the deposits will retain their high $\mathrm{pH}$ in the long term.

\section{Acknowledgements}

Research was funded by Estonian Research Council from National Programme for Addressing Socio-Economic Challenges through R\&D (RITA) which is supported by Estonian Government and European Regional Development. Analytical instruments of Estonian Centre of Analytical Chemistry were used. The authors would like to thank Jaan Aruväli, Marian Külaviir and Signe Vahur for their help with laboratory analyses.

\section{References}

Alarcon-Ruiz, L., Platret, G., Massieu, E., Ehrlacher, A., 2005. The use of thermal analysis in assessing the effect of temperature on a cement paste. Cem. Concr. Res. 35, 609-613. https://doi.org/10.1016/j.cemconres.2004.06.015

Astrup, T., Jakobsen, R., Christensen, T.H., Hansen, J.B., Hjelmar, O., 2006. Assessment of long-term pH developments in leachate from waste incineration residues. Waste Manag. Res. 24, 491-502. https://doi.org/10.1177/0734242X06066963

Barnett, S.J., Adam, C.D., Jackson, A.R.W., 2000. Solid solutions between ettringite, $\mathrm{Ca} 6 \mathrm{Al} 2(\mathrm{SO} 4) 3(\mathrm{OH}) 12 \cdot 26 \mathrm{H} 2 \mathrm{O}$, and thaumasite, $\mathrm{Ca} 3 \mathrm{SiSO} 4 \mathrm{CO} 3(\mathrm{OH}) 6 \cdot 12 \mathrm{H} 2 \mathrm{O}$. J. Mater. Sci. 35, 4109-4114. https://doi.org/10.1023/A:1004898623884

Bensted, J., 1999. Thaumasite - background and nature in deterioration of cements, mortars and concretes. Cem. Concr. Compos., Portland Limestone Cements 21, 117-121. https://doi.org/10.1016/S0958-9465(97)00076-0

Bityukova, L., Mõtlep, R., Kirsimäe, K., 2010. Composition of oil shale ashes from pulverized firing and circulating fluidized-bed boiler in Narva Thermal Power Plants, Estonia. Oil Shale 27, 339. https://doi.org/10.3176/oil.2010.4.07

Blinova, I., Bityukova, L., Kasemets, K., Ivask, A., Käkinen, A., Kurvet, I., Bondarenko, O., Kanarbik, L., Sihtmäe, M., Aruoja, V., Schvede, H., Kahru, A., 2012. Environmental hazard of oil shale 
combustion fly ash. J. Hazard. Mater. 229-230, 192-200.

https://doi.org/10.1016/j.jhazmat.2012.05.095

Chang, J., Fang, Y., Shang, X., 2016. The role of $\beta-\mathrm{C} 2 \mathrm{~S}$ and $\gamma-\mathrm{C} 2 \mathrm{~S}$ in carbon capture and strength development. Mater. Struct. 49, 4417-4424. https://doi.org/10.1617/s11527-016-0797-5

Chen, J.J., Thomas, J.J., Taylor, H.F.W., Jennings, H.M., 2004. Solubility and structure of calcium silicate hydrate. Cem. Concr. Res. 34, 1499-1519. https://doi.org/10.1016/j.cemconres.2004.04.034

Crammond, N.J., 2003. The thaumasite form of sulfate attack in the UK. Cem. Concr. Compos. 25, 809818. https://doi.org/10.1016/S0958-9465(03)00106-9

de Vargas, A.S., Dal Molin, D.C.C., Masuero, Â.B., Vilela, A.C.F., Castro-Gomes, J., de Gutierrez, R.M., 2014. Strength development of alkali-activated fly ash produced with combined $\mathrm{NaOH}$ and $\mathrm{Ca}(\mathrm{OH}) 2$ activators. Cem. Concr. Compos. 53, 341-349. https://doi.org/10.1016/j.cemconcomp.2014.06.012

Duxson, P., Fernández-Jiménez, A., Provis, J.L., Lukey, G.C., Palomo, A., Deventer, J.S.J. van, 2007. Geopolymer technology: the current state of the art. J. Mater. Sci. 42, 2917-2933. https://doi.org/10.1007/s10853-006-0637-z

Filippidis, A., Georgakopoulos, A., 1992. Mineralogical and chemical investigation of fly ash from the Main and Northern lignite fields in Ptolemais, Greece. Fuel 71, 373-376. https://doi.org/10.1016/0016-2361(92)90024-I

Frías, M., Rodriguez, O., Vigil de la Villa, R., García, R., Martínez-Ramírez, S., Fernandez-Carrasco, L.J., Vegas, I., 2016. The Influence of Activated Coal Mining Wastes on the Mineralogy of Blended Cement Pastes. J. Am. Ceram. Soc. 99, 300-307. https://doi.org/10.1111/jace.13840

Fulekar, M.H., Dave, J.M., 2007. Disposal of fly ash — an environmental problem. Int. J. Environ. Stud. 26, 191-215. https://doi.org/10.1080/00207238608710257

García, R., Vigil de la Villa, R., Rodríguez, O., Frías, M., 2009. Mineral phases formation on the pozzolan/lime/water system. Appl. Clay Sci. 43, 331-335. https://doi.org/10.1016/j.clay.2008.09.013

García-Lodeiro, I., Fernández-Jiménez, A., Sobrados, I., Sanz, J., Palomo, A., 2012. C-S-H Gels: Interpretation of 29Si MAS-NMR Spectra. J. Am. Ceram. Soc. 95, 1440-1446. https://doi.org/10.1111/j.1551-2916.2012.05091.x

Gazdič, D., Fridrichová, M., Kulísek, K., Vehovská, L., 2017. The Potential Use of the FBC Ash for the Preparation of Blended Cements. Procedia Eng., International High-Performance Built Environment Conference - A Sustainable Built Environment Conference 2016 Series (SBE16), iHBE 2016 180, 1298-1305. https://doi.org/10.1016/j.proeng.2017.04.292

Gomes, H.I., Mayes, W.M., Rogerson, M., Stewart, D.I., Burke, I.T., 2016. Alkaline residues and the environment: a review of impacts, management practices and opportunities. J. Clean. Prod. 112, 3571-3582. https://doi.org/10.1016/j.jclepro.2015.09.111

Hartshorn, S.A., Sharp, J., Swamy, R.N., 1999. Thaumasite formation in Portland-limestone cement pastes - A cause of deterioration of Portland cement and related substances in the presence of sulphates. Cem. Concr. Res. 29. https://doi.org/10.1016/S0008-8846(99)00100-3

Heidrich, C., Feuerborn, H.-J., Weir, A., 2013. Coal combustion products. A global perspective. VGB PowerTech 93, 46-52.

Kim, M.S., Jun, Y., Lee, C., Oh, J.E., 2013. Use of $\mathrm{CaO}$ as an activator for producing a price-competitive non-cement structural binder using ground granulated blast furnace slag. Cem. Concr. Res. 54, 208-214. https://doi.org/10.1016/j.cemconres.2013.09.011

Konist, A., Maaten, B., Loo, L., Neshumayev, D., Pihu, T., 2016. Mineral sequestration of CO2 by carbonation of Ca-rich oil shale ash in natural conditions. Oil Shale 33, 248. https://doi.org/10.3176/oil.2016.3.04

Lecuyer, I., Gueraud, S., Bursi, J.M., 2001. Different uses of CFB ash - EDF investigations. Presented at the 42nd IEA-FBC Meeting, Sydney, Nova Scotia, Canada. https://www.processeng.biz/ieafbc.org/upload/costa.pdf 
Liira, M., Kirsimäe, K., Kuusik, R., Mõtlep, R., 2009. Transformation of calcareous oil-shale circulating fluidized-bed combustion boiler ashes under wet conditions. Fuel 88, 712-718. https://doi.org/10.1016/j.fuel.2008.08.012

Loo, L., Konist, A., Neshumayev, D., Pihu, T., Maaten, B., Siirde, A., 2018. Ash and Flue Gas from Oil Shale Oxy-Fuel Circulating Fluidized Bed Combustion. Energies 11, 1218. https://doi.org/10.3390/en11051218

Luukkonen, T., Abdollahnejad, Z., Yliniemi, J., Kinnunen, P., Illikainen, M., 2018. One-part alkaliactivated materials: A review. Cem. Concr. Res. 103, 21-34. https://doi.org/10.1016/j.cemconres.2017.10.001

Magi, M., Lippmaa, E., Samoson, A., Engelhardt, G., Grimmer, A.R., 1984. Solid-state high-resolution silicon-29 chemical shifts in silicates. J. Phys. Chem. 88, 1518-1522. https://doi.org/10.1021/j150652a015

Matalkah, F., Xu, L., Wu, W., Soroushian, P., 2017. Mechanochemical synthesis of one-part alkali aluminosilicate hydraulic cement. Mater. Struct. 50. https://doi.org/10.1617/s11527-016-0968-4

McCarthy, M.J., Dhir, R.K., 1999. Towards maximising the use of fly ash as a binder. Fuel 78, 121-132. https://doi.org/10.1016/S0016-2361(98)00151-3

Mõtlep, R., Sild, T., Puura, E., Kirsimäe, K., 2010. Composition, diagenetic transformation and alkalinity potential of oil shale ash sediments. J. Hazard. Mater. 184, 567-573. https://doi.org/10.1016/j.jhazmat.2010.08.073

Myers, R.J., Bernal, S.A., San Nicolas, R., Provis, J.L., 2013. Generalized Structural Description of Calcium-Sodium Aluminosilicate Hydrate Gels: The Cross-Linked Substituted Tobermorite Model. Langmuir 29, 5294-5306. https://doi.org/10.1021/la4000473

Myers, R.J., L’Hôpital, E., Provis, J.L., Lothenbach, B., 2015. Effect of temperature and aluminium on calcium (alumino)silicate hydrate chemistry under equilibrium conditions. Cem. Concr. Res. 68, 83-93. https://doi.org/10.1016/j.cemconres.2014.10.015

Nguyen, L.C., Inui, T., Ikeda, K., Katsumi, T., 2015. Aging effects on the mechanical property of waste mixture in coastal landfill sites. Soils Found. 55, 1441-1453. https://doi.org/10.1016/j.sandf.2015.10.009

Ots, A., 2006. Oil shale fuel combustion. Tallinna Raamatutrükikoda, Tallinn.

Paiste, P., Külaviir, M., Paaver, P., Heinmaa, I., Vahur, S., Kirsimäe, K., 2017. Beneficiation of Oil Shale Processing Waste: Secondary Binder Phases in Alkali Activated Composites. Waste Biomass Valorization. https://doi.org/10.1007/s12649-017-0140-6

Paiste, P., Liira, M., Heinmaa, I., Vahur, S., Kirsimäe, K., 2016. Alkali activated construction materials: Assessing the alternative use for oil shale processing solid wastes. Constr. Build. Mater. 122, 458-464. https://doi.org/10.1016/j.conbuildmat.2016.06.073

Petzrick, P., Lee, R., Litten, J., 2017. Coal ash management beneficial use of fresh and legacy CCBs in Maryland, in: 34th Annual International Pittsburgh Coal Conference: Coal - Energy, Environment and Sustainable Development, PCC 2017.

Raado, L.-M., Kuusik, R., Hain, T., Uibu, M., Somelar, P., 2014. Oil shale ash based stone formation Hydration, hardening dynamics and phase transformations. Oil Shale 31, 91-101. https://doi.org/10.3176/oil.2014.1.09

Rattanasak, U., Chindaprasirt, P., 2009. Influence of $\mathrm{NaOH}$ solution on the synthesis of fly ash geopolymer. Miner. Eng. 22, 1073-1078. https://doi.org/10.1016/j.mineng.2009.03.022

Richardson, I.G., 2004. Tobermorite/jennite- and tobermorite/calcium hydroxide-based models for the structure of C-S-H: applicability to hardened pastes of tricalcium silicate, $\beta$-dicalcium silicate, Portland cement, and blends of Portland cement with blast-furnace slag, metakaolin, or silica fume. Cem. Concr. Res. 34, 1733-1777. https://doi.org/10.1016/j.cemconres.2004.05.034

Richardson, I.G., 1999. The nature of C-S-H in hardened cements. Cem. Concr. Res. 29, 1131-1147. https://doi.org/dx.doi.org/10.1016/S0008-8846(99)00168-4

Richardson, I.G., Cabrera, J.G., 2000. The nature of C-S-H in model slag-cements. Cem. Concr. Compos. 22, 259-266. https://doi.org/10.1016/S0958-9465(00)00022-6 
Scrivener, K., Snellings, R., Lothenbach, B., 2016. A Practical Guide to Microstructural Analysis of Cementitious Materials. CRC Press.

Sear, L., 2006. Pulverised Fuel Ash and Preventing the Thaumasite Form of Sulfate Attack, in: AshTech 2006: Proceedings of the International Conference. Presented at the Ash Technology Conference 2006, UKQAA, Hippodrome Theatre, Birmingham, United Kingdom.

Stutzman, P.E., 2001. Scanning Electron Microscopy in Concrete Petrography, in: Materials Science of Concrete Special Volume: Calcium Hydroxide in Concrete. Proceedings. J. Skalny, J. Gebauer and I. Odler, Eds. John Wiley \& Sons, Anna Maria Island, Florida, pp. 59-72.

Taylor, H.F.W., 1997. Cement chemistry, 2nd ed. T. Telford, London.

Torres, S.M., Kirk, C.A., Lynsdale, C.J., Swamy, R.N., Sharp, J.H., 2004. Thaumasite-ettringite solid solutions in degraded mortars. Cem. Concr. Res. 34, 1297-1305. https://doi.org/10.1016/j.cemconres.2003.09.016

Uibu, M., Kuusik, R., 2014. Main physicochemical factors affecting the aqueous carbonation of oil shale ash. Miner. Eng. 59, 64-70.

Uibu, M., Somelar, P., Raado, L.-M., Irha, N., Hain, T., Koroljova, A., Kuusik, R., 2016. Oil shale ash based backfilling concrete - Strength development, mineral transformations and leachability. Constr. Build. Mater. 102, 620-630. https://doi.org/10.1016/j.conbuildmat.2015.10.197

Ukrainczyk, N., Ukrainczyk, M., Šipušić, J., Matusinović, T., 2006. XRD and TGA Investigation of Hardened Cement Paste Degradation. 11 Int. Conf. Mater. Process. Frict. Wear MATRIB06 243.

Van Deventer, J.S.J., Provis, J.L., Duxson, P., 2012. Technical and commercial progress in the adoption of geopolymer cement. Miner. Eng., Sustainability through Resource Conservation and Recycling 29, 89-104. https://doi.org/10.1016/j.mineng.2011.09.009

Velts, O., Uibu, M., Kallas, J., Kuusik, R., 2013. CO2 Mineralisation: Concept for Co-utilization of Oil Shale Energetics Waste Streams in CaCO3 Production. Energy Procedia 37, 5921-5928. https://doi.org/10.1016/j.egypro.2013.06.518

Yip, C.K., Lukey, G.C., van Deventer, J.S.J., 2005. The coexistence of geopolymeric gel and calcium silicate hydrate at the early stage of alkaline activation. Cem. Concr. Res. 35, 1688-1697. https://doi.org/10.1016/j.cemconres.2004.10.042

Yu, P., Kirkpatrick, R.J., Poe, B., McMillan, P., Cong, X., 1999. Structure of Calcium Silicate Hydrate (C- S- H): Near- , Mid- , and Far- Infrared Spectroscopy. J. Am. Ceram. Soc. 82, 742-748. https://doi.org/10.1111/j.1151-2916.1999.tb01826.x

Yvon, J., Antenucci, D., Jdid, E.-A., Lorenzi, G., Dutre, V., Leclerq, D., Nielsen, P., Veschkens, M., 2006. Long-term stability in landfills of Municipal Solid Waste Incineration fly ashes solidified/stabilized by hydraulic binders. J. Geochem. Explor. 90, 143-155. https://doi.org/10.1016/j.gexplo.2005.09.008

Zhang, Q., Ye, G., 2012. Dehydration kinetics of Portland cement paste at high temperature. J. Therm. Anal. Calorim. 110, 153-158. https://doi.org/10.1007/s10973-012-2303-9

Zhao, S., Duan, Y., Lu, Jincheng, Gupta, R., Pudasainee, D., Liu, S., Liu, M., Lu, Jianhong, 2018. Chemical speciation and leaching characteristics of hazardous trace elements in coal and fly ash from coal-fired power plants. Fuel 232, 463-469. https://doi.org/10.1016/j.fuel.2018.05.135

Zhao, Y., Zhang, J., Tian, C., Li, H., Shao, X., Zheng, C., 2010. Mineralogy and Chemical Composition of High-Calcium Fly Ashes and Density Fractions from a Coal-Fired Power Plant in China. Energy Fuels 24, 834-843. https://doi.org/10.1021/ef900947y 